\title{
Phosphate and potassium fertilization on agronomic and physico-chemical characteristics and bioactive compounds of eggplant
}

\author{
Luciene A. de Oliveira ${ }^{1}$, Ernani C. da Silva² ${ }^{2}$ Lanamar de A. Carlos ${ }^{3}$ \& Gabriel M. Maciel ${ }^{4}$ \\ ${ }^{1}$ Empresa de Assistência Técnica e Extensão Rural do Estado de Minas Gerais. Sete Lagoas, MG, Brasil. E-mail: luciene.oliveira@emater.mg.gov.br - ORCID: \\ 0000-0002-9622-074X \\ ${ }^{2}$ Universidade Federal de São João del-Rei/Departamento de Ciências Agrárias. Sete Lagoas, MG, Brasil. E-mail:clarete@ufsj.edu.br (Corresponding author) \\ - ORCID: 0000-0001-7515-7588 \\ ${ }^{3}$ Universidade Federal de São João del-Rei/Departamento de Engenharia de Alimentos. Sete Lagoas, MG, Brasil. E-mail: lanamar@ufsj.edu.br - ORCID: \\ 0000-0001-8356-2583 \\ ${ }^{4}$ Universidade Federal de Uberlândia/Instituto de Ciências Agrárias. Monte Carmelo, MG, Brasil. E-mail: gabrielmaciel@ufu.br - ORCID: 0000-0001-5391-631X
}

\begin{abstract}
Eggplant is a functional food rich in antioxidants and its consumption brings several benefits to human health. Phenolic compounds and anthocyanins are some of the compounds that interfere in this antioxidant capacity and may be influenced by the mineral nutrition of the plant. The objective was to analyze the effects of potassium and phosphate fertilization on the agronomic and physico-chemical characteristics and bioactive compounds of eggplant fruits. The work was carried out at the Taboquinha Farm, in the municipality of Baldim, MG, at coordinates $19^{\circ} 17^{\prime} 12.5^{\prime \prime} \mathrm{S}$ and $43^{\circ} 54^{\prime} 01^{\prime \prime} \mathrm{W}$, from March to October 2017. The experimental design was randomized blocks in a $4 \mathrm{x} 4$ factorial scheme with four replicates. The factors under study were phosphorus and potassium represented by four doses of $\mathrm{P}_{2} \mathrm{O}_{5}\left(0,60,120\right.$ and $\left.180 \mathrm{~kg} \mathrm{ha}^{-1}\right)$ and four doses of $\mathrm{K}_{2} \mathrm{O}\left(0,25,50\right.$ and $\left.75 \mathrm{~kg} \mathrm{ha}^{-1}\right)$, respectively. It was concluded that potassium and phosphate fertilization did not improve the agronomic and physico-chemical characteristics of eggplant fruits; however, potassium fertilization in greater amounts promoted improvements in the contents of phenolic compounds. The lack of phosphorus increased the anthocyanin content in the fruits, but interfered negatively in their shape. Potassium and phosphate fertilizations produced antagonistic effects on fruit moisture content.
\end{abstract}

Key words: mineral nutrition, anthocyanins, phenolic compounds

\section{Adubação fosfatada e potássica nas características agronômicas, físico-químicas e nos compostos bioativos da berinjela}

RESUMO: A berinjela é um alimento funcional rico em antioxidantes e o seu consumo traz diversos benefícios para a saúde humana. Os compostos fenólicos e antocianinas são alguns dos compostos que interferem nesta capacidade antioxidante, podendo ser influenciados pela nutrição mineral da planta. O objetivo foi analisar efeitos da adubação potássica e fosfatada nas características agronômicas, físico-químicas e nos compostos bioativos de frutos de berinjeleira. O trabalho foi conduzido no Sítio Taboquinha, município de Baldim, MG, sob as coordenadas $19^{\circ} 17^{\prime} 12,5^{\prime \prime} \mathrm{S}$ e $43^{\circ} 54^{\prime} 01^{\prime \prime}$ W no período de março a outubro de 2017. O delineamento experimental utilizado foi de blocos casualizados em esquema fatorial 4 x 4 com quatro repetições. Os fatores em estudo foram fósforo e potássio representados por quatro doses de $\mathrm{P}_{2} \mathrm{O}_{5}\left(0,60,120\right.$ e $\left.180 \mathrm{~kg} \mathrm{ha}^{-1}\right)$ e quatro doses de $\mathrm{K}_{2} \mathrm{O}\left(0,25,50\right.$ e $\left.75 \mathrm{~kg} \mathrm{ha}^{-1}\right)$, respectivamente. Concluiu-se que a adubação potássica e fosfatada não promoveram melhorias nas características agronômicas e físico-químicas nos frutos de berinjeleira; entretanto, a adubação potássica em maiores quantidades promoveu melhorias no teor de compostos fenólicos. A carência de fósforo aumentou o teor de antocianinas nos frutos, mas, interferiu negativamente na sua forma. As adubações potássica e fosfatada produziram efeitos antagônicos na umidade dos frutos.

Palavras-chave: nutrição mineral, antocianinas, compostos fenólicos 


\section{INTRODUCTION}

Eggplant is a functional food rich in antioxidant agents, such as flavonoids, used in the control of high plasmatic levels of cholesterol and in weight loss diets, thus becoming important in dyslipidemia and obesity (Rosa et al., 2011).

In plants under phosphorus (P) deficiency, alteration from the primary metabolism to the secondary metabolism frequently results in accumulation of secondary metabolites, such as flavonoids and indole alkaloids (Vance et al., 2003). Under accentuated $\mathrm{P}$ deficiency, plants exhibit a color ranging from dark green to purple, which indicates accumulation of anthocyanin (Lima, 2009).

Potassium participates in several biochemical reactions that are important and necessary to plant metabolism (NurzyńskaWierdak et al., 2012; Araújo et al., 2014). Alterations in physico-chemical attributes have been observed in bell pepper as a function of potassium (K) doses (Melo et al., 2008).

Phenolic compounds are classified into four groups with subdivisions: flavonoids, phenolic acids, lignins and stilbenes (Carvalho et al., 2006; Cozzolino, 2012). Anthocyanins, which give the skin a purple color, are the compounds responsible for the antioxidant properties attributed to the fruit (GonzálezLavaut et al., 2007). Phenolic compounds have numerous biological effects, such as sequestration of radical oxygen species and modulation of the activity of some specific enzymes, as well as their potential as antibiotic, anti-allergic and anti-inflammatory agents, besides acting in metabolism regulation processes (Cozzolino, 2012).

Thus, the present study aimed to evaluate the effect of phosphate and potassium fertilization on the agronomic and physico-chemical characteristics and on bioactive compounds in eggplant fruits.

\section{Material ANd Methods}

The study was conducted at the Taboquinha Farm, municipality of Baldim, MG, Brazil, at coordinates $19^{\circ} 17^{\prime}$ $12.5^{\prime}$ S, 430 54' $01^{\prime \prime} \mathrm{W}$ and altitude of $718 \mathrm{~m}$, under Aw climate according to Köppen's classification. The experiment used the hybrid eggplant cultivar 'Ciça', developed by EMBRAPA, which is vigorous, measuring 1.1 to $1.5 \mathrm{~m}$ in height and with no thorns on the leaves. It has oblong fruits with bright dark purple color, weighing on average $350 \mathrm{~g}$. The soil was classified as dystrophic Tb Haplic Cambisol (EMBRAPA, 2013) and its chemical analysis, conducted according to Raij et al. (2001), showed initially the following chemical composition: $\mathrm{pH}\left(\mathrm{H}_{2} \mathrm{O}\right)=4.6$; $\mathrm{OM}=2.29 \mathrm{dag} \mathrm{kg}^{-1} ; \mathrm{P}=22.31 \mathrm{mg} \mathrm{dm}{ }^{-3} ; \mathrm{Ca}=2.27 \mathrm{cmol}_{\mathrm{c}} \mathrm{dm}^{-3}$; $\mathrm{Mg}=0.87 \mathrm{cmol}_{\mathrm{c}} \mathrm{dm}^{-3} ; \mathrm{Al}=1.40 \mathrm{cmol}_{\mathrm{c}} \mathrm{dm}^{-3} ; \mathrm{H}+\mathrm{Al}=10.28$ $\mathrm{cmol} \mathrm{dm}^{-3}$; SB and CEC (pH 7.0) $=3.63$ and $13.91 \mathrm{cmol}_{c} \mathrm{dm}^{-3}$; and $\mathrm{V}=26.1 \%$. Seedlings were produced on disposable plastic trays with 200 cells and transplanted to the experimental area at 40 days after sowing.

The following characteristics were analyzed in eggplant: plant height (obtained in centimeters with graduated ruler measured from the lap to the top of the plant); yield (the fruits were weighed at each harvest on a precision scale $(\mathrm{kg})$ extrapolated to hectare); number of fruits per plant (obtained from the total sum of the number of fruits per plot and divided by the number of plants of the plot); average fruit weight (obtained from the total production per plant, in grams, divided by the total number of fruits per plant); ratio between fruit length and transverse diameter (obtained by dividing the length of the fruit with its transverse diameter), with beginning of the evaluations at 80 days after transplant. Also, the moisture content, total soluble solids, total titratable acidity, soluble solids/total titratable acidity ratio (SS/TTA), pH, total phenolic compounds and total anthocyanins were determined.

For laboratory analyses, harvested fruits were properly identified and stored at $-40{ }^{\circ} \mathrm{C}$ in Cold Lab CL800-86V ultra-freezer until the analyses, when they were thawed and homogenized using a food processor. Determinations were carried out in triplicate, and moisture content, total soluble solids (SS) and total titratable acidity (TTA) were determined according to the methodology of AOAC (2012). SS/TTA ratio was obtained by dividing the readings of total soluble solids (SS) by the content in percentage of titratable acidity (TTA). The $\mathrm{pH}$ was determined by potentiometry (AOAC, 2012) using a digital $\mathrm{pH}$ meter, Tekna model T-1000, by directly immersing the electrode in the extract of ground and homogenized fresh fruits. The content of total phenolic compounds was quantified by the Folin-Ciocalteau spectrophotometric method, modified by Neves et al. (2009), whereas the content of total anthocyanins was determined using the method described by Francis (1982).

The concentration of anthocyanin pigments was quantified based on the absorbance, according to Eq. 1:

$$
\mathrm{At}=\frac{(\mathrm{Ab} \times \mathrm{f})}{\varepsilon}
$$

where:

At - anthocyanins, mg of cyanidin-3-glucoside $100 \mathrm{~g}^{-1}$ of fresh matter;

$\mathrm{Ab}$ - absorbance;

f - dilution factor; and,

$\varepsilon \quad$ - molar absorptivity coefficient of cyanidin - 98.2.

The obtained results were expressed in mg of cyanidin-3glucoside E $100 \mathrm{~g}^{-1}$ on fresh basis.

Physico-chemical analyses and quantification of bioactive compounds were carried out at the Laboratory of Food Conservation located at the Federal University of São João del-Rei, Sete Lagoas Campus, MG, Brazil.

The experimental design used as randomized blocks in $4 \mathrm{x}$ 4 factorial arrangement ( 4 doses of $\mathrm{P} \times 4$ doses of $\mathrm{K}$ ), totaling 16 treatments with 4 replicates.

Treatments were distributed into 64 plots, each of which had three plants, and the observation plot was represented by one plant. Four doses of $\mathrm{P}$ fertilization and four doses of $\mathrm{K}$ fertilization were used $(0,50,100$ and $150 \%$ of the recommendation for the crop). $\mathrm{P}_{2} \mathrm{O}_{5}$ doses corresponded to $\mathrm{P} 0=0, \mathrm{P} 1=60, \mathrm{P} 2=120$ and $\mathrm{P} 3=180 \mathrm{~kg} \mathrm{ha}^{-1}$, using single superphosphate as source. $\mathrm{K}_{2} \mathrm{O}$ doses were: $\mathrm{K} 0=0, \mathrm{~K} 1=25, \mathrm{~K} 2$ $=50$ and $\mathrm{K} 3=75 \mathrm{~kg} \mathrm{ha}^{-1}$, using potassium chloride as source.

Spacing was $1.20 \mathrm{~m}$ between rows and $0.80 \mathrm{~m}$ between plants. To avoid interferences between treatments, the blocks were separated by a distance of $1.00 \mathrm{~m}$. 
The $\mathrm{P}$ dose was supplied entirely at planting; $\mathrm{K}$ was applied $40 \%$ at planting and the remaining portion every 15 days, split into four applications. Nitrogen fertilization was applied according to the need of the crop, using ammonium sulfate as source, following the same form of application of potassium chloride.

Irrigation was performed by a drip system, with intervals according to the climatic conditions. A PETROISA ${ }^{\circ}$ dripline was used, with emitters spaced by $15 \mathrm{~cm}$ and flow rate of $7 \mathrm{~L} \mathrm{~m}^{-1} \mathrm{~h}^{-1}$.

Fruit harvest started 80 days after transplanting. The fruits used in the analysis were the first three of each plant (observation plot). After harvest, they were placed in plastic bags with identification of the plot and taken to the laboratory within a maximum of $4 \mathrm{~h}$, where they were weighed, counted and stored in a freezer at $-18^{\circ} \mathrm{C}$ for the subsequent analyses.

The obtained data were subjected to analysis of variance using the program SISVAR 5.6 (Ferreira, 2014) and, for the characteristics which showed significant effects, regression analysis was performed in response to the doses of $\mathrm{P}$ and $K$. When needed, the equations were derived to determine maximum and minimum points, and the significances of their $\mathrm{R}^{2}$ values were tested by $\mathrm{F}$ test.

\section{Results AND Discussion}

There were no significant differences for plant height, number of fruits per plant, mean fruit weight and yield as a function of $\mathrm{P}_{2} \mathrm{O}_{5}$ and $\mathrm{K}_{2} \mathrm{O}$ doses. There was also no significant interaction between factors. Mean plant height was equal to $94.28 \mathrm{~cm}$, number of fruits per plant to 21.24 , mean fruit weight to $200.10 \mathrm{~g}$ and yield to $45.15 \mathrm{t} \mathrm{ha}^{-1}$. This may be related to high initial contents of $\mathrm{P}$ in the soil, as shown in the analytical results. The values found in the present study differ from those found by Almeida Monaco et al. (2016), who evaluated the eggplant cultivar 'Ciça' under different doses of $\mathrm{K}_{2} \mathrm{O}$ and observed higher values for mean fruit weight $(265.6 \mathrm{~g})$ and lower values for plant height $(66.2 \mathrm{~cm})$, number of fruits (17.69) and maximum yield $\left(24.97 \mathrm{tha}^{-1}\right)$.

In response to the applied doses of $\mathrm{P}_{2} \mathrm{O}_{5}$, the means of fruit length/transverse diameter ratio fitted to a linear equation. As $\mathrm{P}_{2} \mathrm{O}_{5}$ doses increased, this ratio also increased (Figure 1). Higher ratios indicate fruits that are longer or closer to the normal characteristic, which is the oblong shape.

Fruits produced in the absence of $\mathrm{P}$ were flatter compared to those produced under higher doses of this nutrient, which

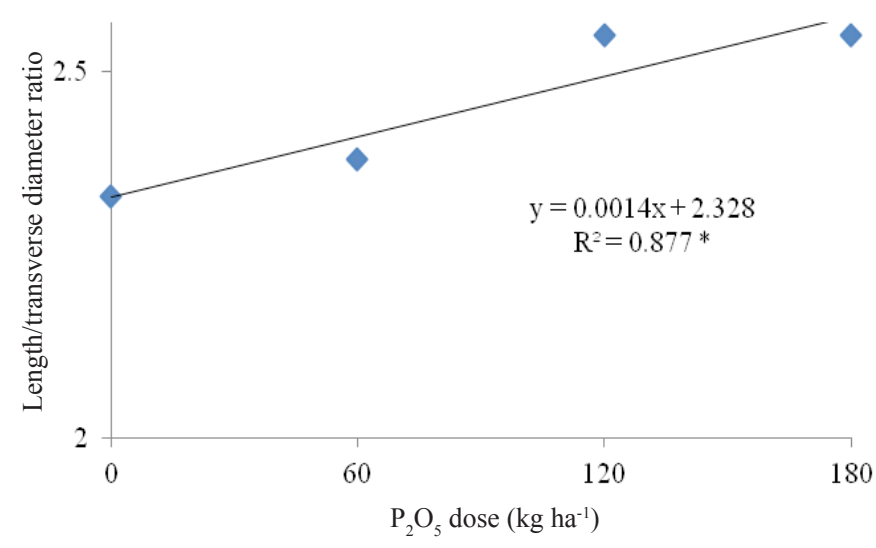

* Significant at 0.05 probability level

Figure 1. Length/transverse diameter ratio in eggplant fruits as a function of phosphate fertilization were more elongated. The elongated shape is the most preferred by Brazilian consumers.

There were no significant effect for $\mathrm{pH}$, total soluble solids, total titratable acidity and SS/TTA ratio as a function of $\mathrm{P}_{2} \mathrm{O}_{5}$ and $\mathrm{K}_{2} \mathrm{O}$ doses, and there was also no interaction between factors.

The following average values were found in the fruits: $\mathrm{pH}$ - 5.12 , total soluble solids $-5.5^{\circ} \mathrm{Brix}$, total titratable acidity $0.12 \mathrm{~g}$ citric acid $100 \mathrm{~g}^{-1}$ (fresh basis) and SS/TTA ratio - 47.26. San José et al. (2013) found pH of 5.44. Heras et al. (2013), analyzing fruits of the eggplant cultivars 'Morada' and 'Lila', found $\mathrm{pH}$ values of 5.59 and 4.47 and acidity of 0.14 and $0.2 \%$ of citric acid, respectively. These characteristics, which are associated with fruit quality, directly influence the taste. Eggplant is part of the a group of vegetables (fruits) classified as of low acidity (those with $\mathrm{pH}$ higher than or equal to 4.5). The content of total soluble solids is related to the content of sugars and SS/TTA ratio, and is an indication of taste (Chitarra \& Chitarra, 2005).

In the present study, fruits had average soluble solids content of $5.5^{\circ}$ Brix, which is higher than those found in studies conducted by several authors: Muy et al. (2002) analyzed the pulp of five eggplant cultivars and found mean value of 3.9 ${ }^{\circ}$ Brix; Gisbert et al. (2011) found values from 4.02 to 4.18 ${ }^{\circ}$ Brix for different eggplant varieties; and Heras et al. (2013), analyzing fruits of the eggplant cultivars 'Morada' and 'Lila', found values of 4.39 and $4.83^{\circ}$ Brix, respectively.

There was significant interaction between phosphate and potassium fertilization doses, with interference in the moisture content. The increase of moisture content in the fruits as a function of $\mathrm{P}$ supply followed a quadratic model, with significance only for the $\mathrm{K}_{2} \mathrm{O}$ doses of 50 and $75 \mathrm{~kg} \mathrm{ha}^{-1}$ (Figure 2). Maximum $\mathrm{P}_{2} \mathrm{O}_{5}$ doses were 110 and $111 \mathrm{~kg} \mathrm{ha}^{-1}$ for $\mathrm{K}_{2} \mathrm{O}$ doses 50 and $75 \mathrm{~kg} \mathrm{ha}^{-1}$, with moisture contents of 92.41 and $92.29 \%$, respectively.

For the nutrition with $\mathrm{K}$, the $\mathrm{P}_{2} \mathrm{O}_{5}$ doses of 0 and $60 \mathrm{~kg} \mathrm{ha}^{-1}$ fitted to a linear model while the $\mathrm{P}_{2} \mathrm{O}_{5}$ dose of $120 \mathrm{~kg} \mathrm{ha}^{-1}$ fitted to a quadratic model (Figure 3 ). In the absence of $\mathrm{P}$, there was a reduction in the moisture content as the $\mathrm{K}_{2} \mathrm{O}$ dose increased. With the application of $60 \mathrm{~kg} \mathrm{ha}^{-1}$ of $\mathrm{P}_{2} \mathrm{O}_{5}$, the moisture content increased as the $\mathrm{K}_{2} \mathrm{O}$ dose increased. For the $\mathrm{P}_{2} \mathrm{O}_{5}$ dose of $120 \mathrm{~kg} \mathrm{ha}^{-1}$, maximum moisture content of $92.26 \%$ occurred at $\mathrm{K}_{2} \mathrm{O}$ dose of $69 \mathrm{~kg} \mathrm{ha}^{-1}$, decreasing

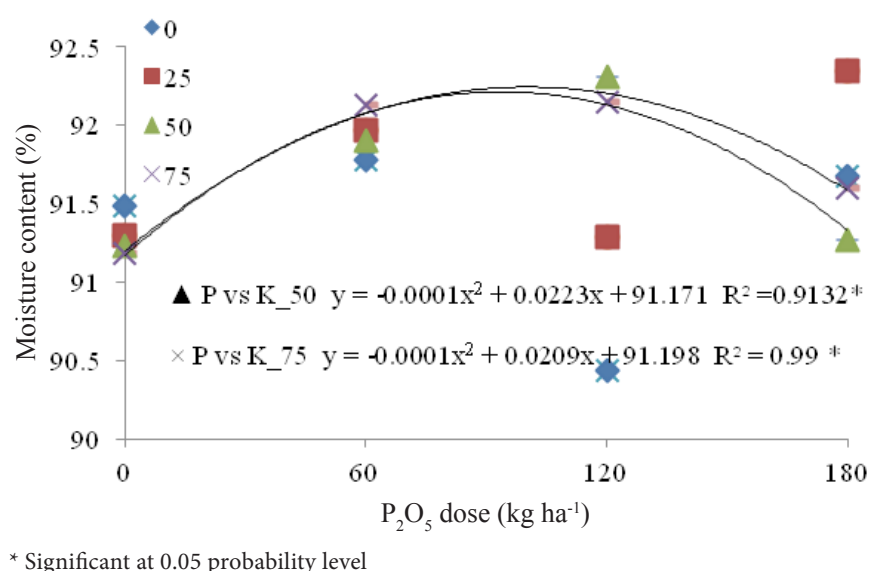

Figure 2. Moisture content in eggplant fruits as a function of phosphate fertilization at different doses of $\mathrm{K}_{2} \mathrm{O}$ 


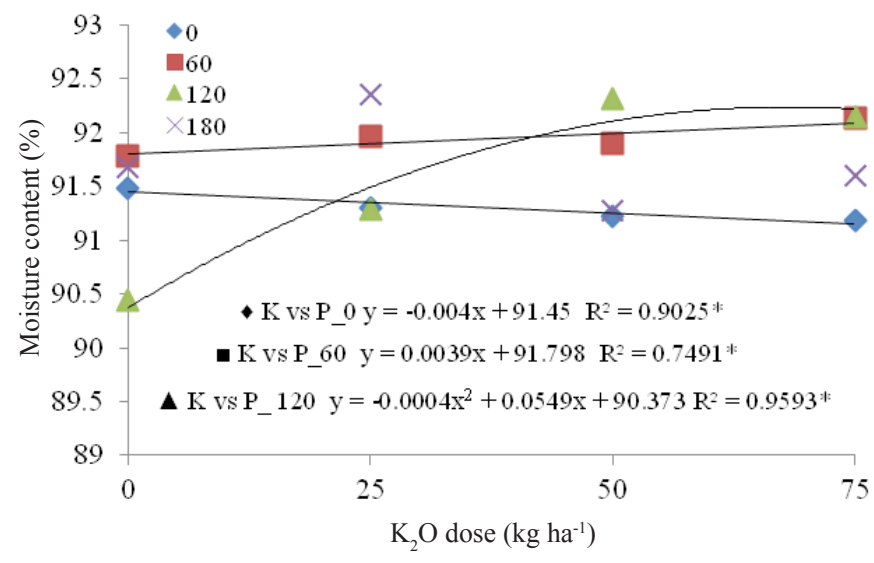

* Significant at 0.05 probability level

Figure 3. Moisture content in eggplant fruits as a function of potassium fertilization at different doses of $\mathrm{P}_{2} \mathrm{O}_{5}$

from this point on. In relation to the dose of $180 \mathrm{~kg} \mathrm{ha}^{-1}$ of $\mathrm{P}_{2} \mathrm{O}_{5}$, there was no consistency of the values observed with equation adjusted to a model of third degree equation without biological explanation.

Adequate nutrition of $\mathrm{K}$ leads to increase in the content of soluble solids, causing lower moisture content (Meurer, 2009).

San José et al. (2013), studying seven eggplant varieties, observed average moisture content of $93 \%$. This value is higher than that found in the present study, which was $91.6 \%$. Although there was significant interaction between factors, the variation of moisture content remained within the normal range for eggplant, thus not reaching qualitative importance. It was observed that inadequate $\mathrm{P}$ supply, as well as increase in $\mathrm{K}$ content, contributed to the production of fruits with lower moisture content, which is a desirable characteristic for better postharvest conservation.

In terms of bioactive compounds, the analyzed eggplant fruits showed statistically different contents of phenolic compounds in response to the treatments with $\mathrm{K}$ doses; and the interaction between factors was not significant.

In response to the applied doses, the means of phenolic compounds fitted to the quadratic model, in which the estimated $\mathrm{K}_{2} \mathrm{O}$ dose of $72 \mathrm{~kg} \mathrm{ha}^{-1}$ led to highest content of phenolic compounds, corresponding to $40.83 \mathrm{mg} \mathrm{GAE} 100 \mathrm{~g}^{-1}$ (Figure 4).

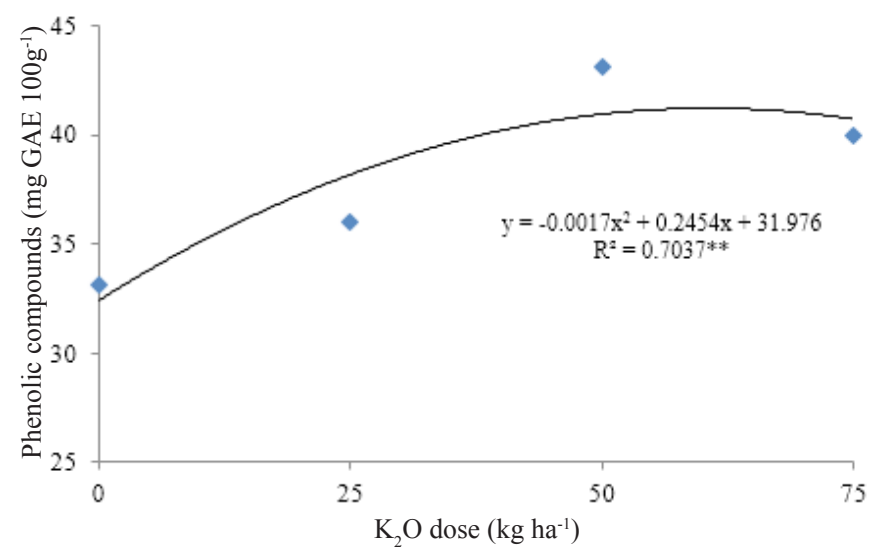

** Significant at 0.01 probability level

Figure 4. Phenolic compounds in eggplant fruits as a function of potassium fertilization
Heras et al. (2013) found contents of total phenolic compounds of 29.72 and $62.5 \mathrm{mg}$ GAE $100 \mathrm{~g}^{-1}$ of fresh pulp in the varieties 'Morada' and 'Lila', respectively. Raigón et al. (2008) observed average contents of phenolic compounds in different eggplant varieties from 34.46 and $60.70 \mathrm{mg}$ GAE $100 \mathrm{~g}^{-1}$ of fresh pulp. Zambrano-Moreno et al. (2015), analyzing phenolic compounds in fresh eggplant fruits under conventional and organic cultivation, found values of 63.99

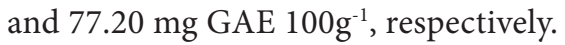

Comparing the data obtained in the present study with the values found by the above-mentioned authors, the contents of phenolic compounds are similar. Phenolic compounds are important structures which have natural antioxidant activity, and studies show that, if eaten regularly, they increase well-being and prevent CNCDs (chronic noncommunicable diseases), such as inflammations and some types of cancer (Silva et al., 2010). Thus, eggplant is known for bringing benefits to the consumer's health because it has in its composition components with functional properties (from the nutritional/medicinal point of view). Hence, the present study brings information that allows fertilization to be associated with the bio production of an important class of secondary metabolites, i.e. phenolic compounds, and this class includes anthocyanins, which are pigments responsible for the eggplant skin color (purple). These pigments are able to neutralize free radicals which are produced in excess and are related to damage to human health (Lopes et al., 2007).

$\mathrm{K}$ has influence on the content of phenolic compounds because it is related to photosynthesis and biosynthesis of starch and proteins. As $\mathrm{K}$ doses increase in the plant, the production of photosynthates increases, which can increase the transfer of the excess of carbon fixed to the shikimic acid pathway, which is the pathway for the formation of phenolic compounds, which may increase the content of phenolic compounds in the plant (Crozier et al., 2006). Continuous intake of foods rich in phenolic compounds in general is associated with the prevention of several types of degenerative diseases. Phenolic compounds, originated from the secondary metabolism, besides being linked to plant defense actions, are important natural antioxidants, a property responsible for the interception of free radicals generated by cell metabolism or exogenous sources which lead to loss of cell integrity. Antioxidants obtained from the diet, such as vitamins C, E and $\mathrm{A}$, phenolic compounds and carotenoids, are extremely important in the interception of free radicals (Bianchi \& Antunes, 1999).

Significant difference was found in the contents of anthocyanins for the different doses of $\mathrm{P}_{2} \mathrm{O}_{5}$. A decreasing linear response was observed in the anthocyanin contents as the supply of $\mathrm{P}$ in the soil increased, with values of $2.41 \mathrm{mg}$ cyanidin-3-glucoside $\mathrm{E} 100 \mathrm{~g}^{-1}$ on fresh basis, at $\mathrm{P}_{2} \mathrm{O}_{5}$ dose of 0 (Figure 5), representing an increase of $47.80 \%$ compared to the recommended dose of $\mathrm{P}\left(180 \mathrm{~kg} \mathrm{ha}^{-1}\right.$ of $\left.\mathrm{P}_{2} \mathrm{O}_{5}\right)$.

In plants under $\mathrm{P}$ deficiency, there is alteration from the primary metabolism to the secondary metabolism, resulting in accumulation of secondary metabolites such as flavonoids (Vance et al., 2003), which encompass the class of anthocyanins, important pigments that, besides giving color 


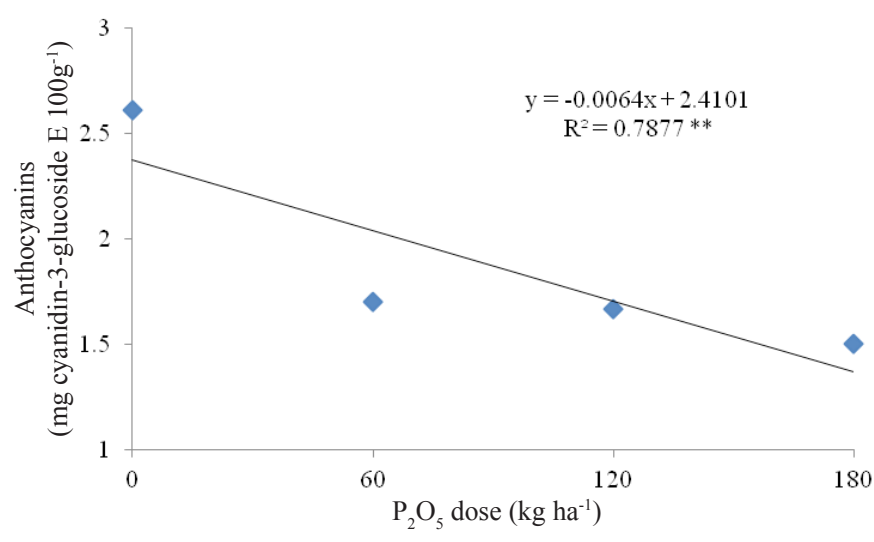

** Significant at 0.01 probability level

Figure 5. Content of anthocyanins in eggplant as a function of phosphate fertilization

to eggplants, increasing its acceptance and consequently its commercialization, are also related to antioxidant properties, which allows the regular consumption of this food to positively affect the consumer's health. Increase of anthocyanins, besides influencing eggplant color, also increases the antioxidant action, a characteristic linked to the prevention of several cardiovascular, cancerous and neurological diseases (Harborne \& Williams, 2000; Sánchez-Moreno, 2002).

Similar results were found by Heras et al. (2013), 2.00 and $2.78 \mathrm{mg}$ cyanidin-3-glucoside $\mathrm{E} 100 \mathrm{~g}^{-1}$ in the eggplant varieties 'Morada' and 'Lila', respectively. In contrast, some authors have found higher values, such as Zambrano-Moreno et al. (2015), who analyzed fresh eggplant fruits in two types of cultivation (conventional and organic) and found average anthocyanin contents of $6.31 \mathrm{mg}$ cyanidin-3-glucoside E $100 \mathrm{~g}^{-1}$ (conventional) and 1.19 mg cyanidin-3-glucoside $\mathrm{E} 100 \mathrm{~g}^{-1}$ (organic). Braga et al. (2011) found anthocyanin contents of $7.0 \mathrm{mg}$ cyanidin-3glucoside $\mathrm{E} 100 \mathrm{~g}^{-1}$ in fresh fruits. Such variation indicates that anthocyanin contents are also influenced by genetic factors and cultivation system.

Since the anthocyanin content can be a criterion of choice in the diet, due to health benefits (Calvete et al., 2008), the consumer will ingest higher contents of anthocyanins when consuming eggplants produced in the absence of phosphate fertilization. On the other hand, it is important to note that, since they are secondary metabolites, these substances are bioproduced under conditions of plant stress and the producer would reduce the production costs. There would be risks in the commercialization due to the undesired shape of the fruit for direct consumption, but it could be directed to the pharmaceutical industry.

\section{Conclusions}

1. Potassium and phosphate fertilization did not improve the agronomic and physico-chemical characteristics of eggplant fruits.

2. Potassium fertilization in greater amounts improved the content of phenolic compounds in eggplant fruits.

3. Lack of phosphorus in eggplant nutrition increased anthocyanin contents in the fruits, but negatively interfered with their shape.
4. Potassium and phosphate fertilizations have antagonistic effects on the moisture content of eggplant fruits.

5. Phosphate fertilization management points to a possible alternative to make eggplant fruits biofortified.

\section{ACKNOWLEDGMents}

The authors thank Mrs. Julieta Alves da Paixão and Mr. Domingos José Vítor da Paixão, for providing the area for the study to be conducted.

\section{Literature Cited}

Almeida Monaco, K. de; Borelli, A. B.; Biscaro, G. A.; Motomiya, A. V. de A.; Zomerfeld, P. dos S. Crescimento, produção e composição química de berinjela 'Ciça' sob fertirrigação potássica. Acta Biológica Colombiana, v.21, p.423-430, 2016. https://doi. org/10.15446/abc.v21n2.47849

AOAC - Association of Official Analytical Chemistry. Official methods of analysis. 19.ed. Gaithersburg: AOAC, 2012. 3000p.

Araújo, H. de S.; Cardoso, A. I. I.; Evangelista, R. M.; Takata, W. H. S.; Silva, E. G. da S. Características físico-químicas de frutos de abobrinha-de-moita em função de doses de potássio em cobertura. Revista Colombiana de Ciencias Hortícolas, v.8, p.242249, 2014. https://doi.org/10.17584/rcch.2014v8i2.3217

Bianchi, M. de L. P.; Antunes, L. M. G. Radicais livres e os principais antioxidantes da dieta. Revista de Nutrição, v.12, p.123-130, 1999. https://doi.org/10.1590/S1415-52731999000200001

Braga, P. C.; Wang, Y. Y.; Sasso, M. D.; Culici, M.; Verducci, P.; Fibiani, M.; Scalzo, R. Inhibitory effects on human neutrophil bursts of raw, grilled and boiled eggplant (Solanum melongena L.). Spatula DD, v.1, p.129-135, 2011. https://doi.org/10.5455/ spatula.20110616110705

Calvete, E. O.; Mariani, F.; Wesp, C. de L.; Nienow, A. A.; Castilhos, T.; Cecchetti, D. Fenologia, produção e teor de antocianinas de cultivares de morangueiro em ambiente protegido. Revista Brasileira de Fruticultura, v.30, p.396-401, 2008. https://doi. org/10.1590/S0100-29452008000200022

Carvalho, P. G. B. de; Machado, C. M. M.; Moretti, C. L.; Fonseca, M. E. de N. Hortaliças como alimentos funcionais. Horticultura Brasileira, v.24, p.397-404, 2006. https://doi.org/10.1590/S010205362006000400001

Chitarra, M. I. F.; Chitarra, A. B. Pós-colheita de frutos e hortaliças: Fisiologia e manuseio. 2.ed. rev. ampl. Lavras: Editora UFLA, 2005. 783p.

Cozzolino, S. M. F. Biodisponibilidade de nutrientes. 4.ed. Barueri: Editora Manole, 2012. 1334p.

Crozier, A.; Jaganath, I. B.; Clifford, M. N. Phenols, polyphenols and tannins: An overview. In: Crozier, A.; Clifford, M. N.; Ashihara, H. (eds.). Plant secondary metabolites: Occurrence, structure and role in the human diet. Oxford: Blackwel Publishing, 2006. Chap.1, p.1-24. https://doi.org/10.1002/9780470988558.ch1

EMBRAPA - Empresa Brasileira de Pesquisa Agropecuária. Sistema brasileiro de classificação de solos. 3.ed. Brasília: Embrapa Informação Tecnológica, 2013. 353p.

Ferreira, D. F. Sisvar: A guide for its bootstrap procedures in multiple comparisons. Ciência e Agrotecnologia, v.38, p.109-112, 2014. https://doi.org/10.1590/S1413-70542014000200001 
Francis, F. J. Analysis of anthocyanins. In: Markakis, P. (ed.). Anthocyanins as food colors. New York: Academic Press, 1982. Chap.7, p.181-207. https://doi.org/10.1016/B978-0-12-4725508.50011-1

Gisbert, C.; Prohens, J.; Raigón, M. D.; Stommel, J. R.; Nuez, F. Eggplant relatives as sources of variation for developing new rootstocks: Effects of grafting on eggplant yield and fruit apparent quality and composition. Scientia Horticulturae, v.128, p.14-22, 2001. https://doi.org/10.1016/j.scienta.2010.12.007

González-Lavaut, J. A.; Oca-Rojas, Y. M. de; Domínguez-Mesa, M. I. Breve reseña de la espécie Solanum melongena L. Revista Cubana de Plantas Medicinales, v.3, p.1-13, 2007.

Harborne, J. B.; Williams, C. A. Advances in flavonoid research since 1992. Phytochemistry, v.52, p.481-504, 2000. https://doi. org/10.1016/S0031-9422(00)00235-1

Heras, I.; Alvis, A.; Arrazola, G. Optimización del proceso de extracción de antocianinas y evaluación de la capacidad antioxidante de berenjena (Solana melonera L.). Información Tecnológica, v.24, p.93-102, 2013. https://doi.org/10.4067/ S0718-07642013000500011

Lima, S. S. de. Crescimento, composição mineral e sintomas visuais de deficiências de macronutrientes em plantas de Zingiber spectabilis Griff. Belém: UFRA, 2009. 84p. Dissertação Mestrado

Lopes, T. J.; Xavier, M. F.; Quadri, M. G. N.; Quadri, M. B. Antocianinas: Uma breve revisão das características estruturais e da estabilidade. Revista Brasileira de Agrociência, v.13, p.291297, 2007

Melo, A. S. de; Brito, M. E. B.; Dantas, J. D. de M.; Silva Júnior, C. D. da; Fernandes, P. D.; Bonfim, L. V. Produção e qualidade do pimentão amarelo sob diferentes níveis de potássio em ambiente protegido. Revista Brasileira de Ciências Agrárias, v.4, p.1721,2008. https://doi.org/10.5039/agraria.v4ila3

Meurer, E. J. Potássio. In: Fernandes, M. S. (ed). Nutrição mineral de plantas. Viçosa: Sociedade Brasileira de Ciência do Solo, 2009. Cap.11, p.281-298.

Muy-Rangel, D.; Siller-Cepda, J.; García-Estrada, R.; Báez-Sañudo, M. Caracterización pos cosecha de berenjenas producidas em Sinaloa, México. Revista Chapingo Serie Horticultura, v.8, p.171181, 2002. https://doi.org/10.5154/r.rchsh.2000.11.073
Neves, L. C.; Alencar, S. M. de; Carpes, S. T. Determinação da atividade antioxidante e do teor de compostos fenólicos e flavonoides totais em amostras de pólen apícola de Apis mellifera. Brazilian Journal of Food Technology, v.15, p.107-110, 2009.

Nurzyńska-Wierdak, R.; Dzida, K.; Rożek, E.; Jarosz, Z. Effects of nitrogen and potassium fertilization on growth, yield and chemical composition of garden rocket. Acta Scientiarum. Polonorum, v.11, p.289-300, 2012.

Raigón, M. D.; Prohens, J.; Muñoz- Falcón, J.; Nuez, F. Comparison of eggplant landraces and commercial varieties for fruit content of phenolics, minerals, dry matter and protein. Journal of Food Composition and Analysis, v.21, p.370-376, 2008. https://doi. org/10.1016/j.jfca.2008.03.006

Raij, B. van; Andrade, J. C. de; Cantarella, H.; Quaggio, J. A. (eds.). Análise química para avaliação da fertilidade de solos tropicais. Campinas: Instituto Agronômico de Campinas, 2001. 285p.

Rosa, G.; Pimentel, A. C.; Monteiro, W. A. Comparação da suplementação de farinha de linhaça marrom desengordurada e farinha de berinjela na redução dos fatores de risco cardiovascular. Revista Brasileira de Cardiologia, v.24, p.95-99, 2011.

San José, R.; Sánchez, M. C.; Cámara, M. M.; Prohens, J. Composition of eggplant cultivars of the occidental type and implications for the improvement of nutritional and functional quality. Internacional Journal of Food Science and Technology, v.48, p.2490-2499, 2013. https://doi.org/10.1111/ijfs. 12240

Sánchez-Moreno, C. Methods used to evaluate the free radical scavenging activity in foods and biological systems. Food Science and Technology International, v.8, p.121-137, 2002.

Silva, M. L. C.; Costa, R. S.; Santana, A. dos S.; Koblitz, M. G. B. Compostos fenólicos, carotenóides e atividade antioxidante em produtos vegetais. Semina: Ciências Agrárias, v.31, p.669-682, 2010. https://doi.org/10.5433/1679-0359.2010v31n3p669

Vance, C. P.; Uhde-Stone, C.; Allan, D. L. Phosphorus acquisition and use: Critical adaptations by plants for securing a nonrenewable resource. New Phytologist, v.157, p.423-447, 2003. https://doi. org/10.1046/j.1469-8137.2003.00695.x

Zambrano-Moreno, E. L.; Chávez-Jáuregui, R. N.; Plaza, M. de L.; WesselBeaver, L. Phenolic content and antioxidant capacity in organically and conventionally grown eggplant (Solanum melongena) fruits follwing thermal processing. Food Science and Technology, v.35, p.414-420, 2015. https://doi.org/10.1590/1678-457X.6656 